\title{
Does Green Innovation Matter? A Study on Indonesia's SMEs
}

\author{
Setyo Ferry Wibowo, Gatot Nazir Ahmad, and Achmad Fauzi \\ Faculty of Economics, Universitas Negeri Jakarta \\ setyoferry@unj.ac.id andahmad72nazir@gmail.com
}

\begin{abstract}
This study examines the effect of green innovation on competitive advantage and company performance. A Survey of 200 top managers and owners of SMEs in Indonesia was conducted to gather the data. Structural Equation model was used to examine the measurement model and the structural model. The hypotheses test results state that green innovation has a positive effect on competitive advantages and competitive advantages influence the company's non-green performance. However, green innovation and green competitive advantage have not proven to influence the company's green performance. Also, green performance has not been proven to affect non-green performance. This study contributes academically to the development of green innovation and company performance literature in the context of SMEs in developing countries, which is under-researched.
\end{abstract}

Keywords: green innovation, competitive advantage, green performance, SMEs.

\section{INTRODUCTION}

The green business model literature has proliferated (Andersen, 2015). The development of the green business model represents a paradigm shift which put the environment as an opportunity instead of a burden (Andersen, 2012). The company's efforts to take advantage of these opportunities ranging from artificial to the comprehensive effort by changing the company's orientation and strategy.

The benefits of implementing a green business model are accrued by the environment, consumers, as well as the company. (Henriksen et al., 2012) state that a green business model allows companies to gain competitive advantage through increasing the company's reputation (Covino et al., 2013; Saeidi et al., 2015), efficient use of resources, and reduce production costs. This competitive advantage will last not only in the short term but also in the long term. In addition, the green business model also opens opportunities for acquiring new markets/consumers (Covino et al., 2013).

Small and medium-sized enterprises (SMEs) are considered as a critical factor which determines economic growth. Regard to the increasing of environmental concern, SMEs should consider environmental issues (Weng and Lin, 2011). Compare to large companies, SMEs are perceived to be less conscious of the negative impact of their operation and lack interest in implementing green business (Sáez-Martínez et al., 2016). Hence, investigating the green business in SMEs context will be valuable.

The competitive advantage in green business models can be obtained through innovation carried out by companies (Henriksen, 2011). Green innovation can radically change the value chain, organizational models, value creation, and forms of relationships with consumers that will improve company performance. However, green innovation literature still developing due to the complexity and influence of environmentally friendly innovations (Verde, 2015) and inconsistent results (Rosenbusch et al., 2011). Furthermore, 
there is a lack of investigations have addressed green innovation in SMEs context (Pinget et al., 2015).

Firms should maximize their effort in establishing green innovation so that they can strengthen their competitiveness (Tseng et al., 2012). However, innovation involves uncertainty and risk and requires many resources in the process. Thus, understanding green innovation will help firms, particularly SMEs to achieve the best results.

Company performance often investigated as the consequences of green innovation. Previous studies have proven the influence of green innovations on company performance. Green innovation will enhance company performance (Zhang and Walton, 2016). These results support prior studies (Ar, 2012; Chan et al., 2016).

However, most of these studies measured company performance with only financial and operational size dimensions. There are only a few studies that also use green performance measures. Green innovation has effect on green performance and non-green performance (Weng et al., 2015). However, the study did not analyze the impact of green performance on non-green performance.

According to the authors, the increase in green performance will impact on reducing production costs which in turn affects the selling price and the number of sales. Also, managing a business in a green manner can improve the company's reputation. Thus, green performance should influence non-green performance. However, regardless of the attention of scholars in investigating the effect of environmental performance on financial performance, the results of this studies still contradictory (Albertini, 2013). Therefore, this study aims to investigate the effect of green performance on non-green performance.

Green innovation also will affect the company's competitive advantage given that innovation is one form of company capability that is a source for the creation of competitive advantage. Thus, we include competitive advantage in the model as the consequences of green innovation.

The objective of the study is to examine the effect of green innovation on competitive advantage and company performance. Notably, the study contributes a valuable insight in examining the relationship between green performance and non-green performance. This study seeks to contribute to green innovation literature, specifically in explaining the impact of green innovations on competitive advantage and corporate performance.

SMEs in Indonesia on national income has shown a significant increasing contribution in the last five years, from $57.84 \%$ to $60.34 \%$ (AHA/SON/NDY, 2018). However, several problems should be solved to improve SMEs' performance level. Besides of access to financial resources, human resources quality, and legal entity problems, innovation is another fundamental problem faced by SMEs in Indonesia. SMEs in Indonesia lack of competitive advantage (Beselly and Mawardi, 2017). This competitive advantage issue is a result of the underemployment of innovation by SMEs (Ussisa, 2015).

\section{THEORETICAL REVIEW}

Natural Resource-Based View Theory. The relationship among innovation, competitive advantage, and performance is captured by natural resource-based view theory (RBV), which investigates the role of internal factors which support the creation of firm's competitive advantage, namely resources and capabilities. Resource is anything that 
possessed by firm, both tangible and intangible. It includes physical and financial assets, employees' skill and organizational process. Capability is the ability of firm to perform a certain kind of action, which stems from resources.

Regardless to the contribution of the theory in explaining how firms can accrue their competitive advantage and achieving superior performance, RBV not take into account the importance of the relationship between the organization and its environment, particularly natural environment (Dowell and Hart, 2011). Natural Resource-Based View Theory (NRBV) as the extension of RBT attempts to cover this omission. According to NRBV, there are three keys strategic capabilities: pollution prevention, product stewardship, and sustainable development. For each of those, innovation is an essential element.

Company Performance. Company performance is "corporate performance management processes in relations to corporate goals" (Fauzi et al., 2010). Formerly, most researchers focused on the dimensions of financial performance as a single measure of company performance. "Financial performance is a meta-construct emphasizing the profitability of the firm" (Albertini, 2013, p. 435). Return on investment (ROI), internal rate of return, and market share are indicators that are often used to measure a company's financial performance. Later, many researchers developed other measures besides financial performance. Company performance includes both financial and non-financial (Weng et al., 2015).

As the awareness of the environment increases, scholars have included environmental dimensions as one measure of company performance (Fraj et al., 2011; Laosirihongthong et al., 2013). Green performance is the company's ability to produce at a low cost, reduce energy consumption, use recycled materials, in order to protect the natural environment (Gholami et al., 2013). Green performance also described as the results gained by firm in managing environmental aspects (Trumpp et al., 2015).

This study divides company performance into two variables; green performance and non-green performance, which includes financial and operational performance.

Green Innovation. Consciousness about the importance of green innovation has grown meaningfully in the past two decades (del Río et al., 2016; Peng and Liu, 2016). Since environmental issues were recognized plays an essential role in defining the company's competitiveness, the eco-friendly aspect has become a part of innovation research (Schiederig et al., 2012). Green innovation enables firms to minimize negative externalities and allow them to gain environmental benefits (Wong et al., 2014). Green innovation offers a bundle of benefit for SMEs in terms of reducing cost, reducing risk, increase reputation as well as brand value, and create innovation capabilities (Schaltegger, 2011).

Green innovation is the development of new products and changes to the process or method of production which has more concern on the environment (Oxborrow and Brindley, 2013). There are three types of green innovation, eco-process, eco-product, and ecoorganizational innovations (Triguero et al., 2013). Eco-process innovation involves new elements implemented into the production system to produce eco-products (Negny et al., 2012). Furthermore, eco-process innovation refers to "the improvement of existing production processes or the addition of new processes to reduce environmental impact" (Negny et al., 2012). Eco-product innovation refers to products improvement or developing new products which have minimal impact on the environment (Peng and Liu, 2016). 
Furthermore, green product is considered as the critical element for firms to obtain competitive advantage (Tseng et al., 2012). Eco-management defined as "organizational capabilities and commitment to implement new forms of eco-innovation management, e.g., pollution prevention schemes, environmental management and auditing system" (Cheng and Shiu, 2012)

Green innovation studies can be classified into strategic sustainability behavior and the pursued innovation types (Klewitz and Hansen, 2014). While strategic sustainability behavior focuses on the type of reactions performed by SMEs, pursued innovation type focuses on identifying elements in each green innovation forms.

Another point of view of the studies revealed that the drivers of green innovation include government policy, stakeholders, organizational strategies, organizational leadership, organizational culture, and the characteristics of the eco-innovation (Cheng, 2014). The study in line with other studies (Berrone et al., 2013; Chou et al., 2012; Kesidou and Demirel, 2012). However, the success of green innovation depends on how consumers respond to it. Furthermore, scholars have recognized that consumers will built a perception about product innovativeness based on their evaluation of its newness (Zhang et al., 2016).

Competitive Advantage. Competitive advantage defined as: "a firm's consistent profits over rival firms that deliver services that cannot be matched easily" (Arseculeratne and Yazdanifard, 2014). Furthermore, "business firms use diverse strategies to gain a competitive advantage over rivals" (Arseculeratne and Yazdanifard, 2014).

The concept of competitive advantage is often interchanged with performance. However, the two concepts are distinguished (Powell, 2001). Competitive advantage is defined as the implementation of a value-creating strategy which is not being implemented yet by any current or potential competitors (Strand and Freeman, 2015). In other words, competitive advantage is the economic value created by the company as a result of utilizing resource capabilities (Newbert, 2008). Firm performance is defined as the total value created by the firm through its activities, which is the sum of the utility created or each of a firm's legitimate stakeholders (Harrison and Wicks, 2013).

Hypotheses Development. Green Innovation and Green Performance. Green innovation refers to "an instrument to improve firms' environmental management process" (Guoyou et $a l ., 2013)$. In the theory of resource-based view perspectives, product innovation can be considered as a company-owned resource that enables companies to gain a competitive advantage and simultaneously improve company performance (Hasan and Ali , 2015).

Previous study (Doran and Ryan, 2012) concluded green innovation has a positive and significant impact on company performance. Another study (Ar, 2012) also found that the green innovation product affected the company's performance and competitive advantage. It has been proven that green innovation affects company performance and environmental performance (Chen et al., 2015).

Based on the description above, the research hypothesis is proposed as follows:

H1: green innovation positively affects green performance

Green Innovation and Competitive Advantage. Innovation strategy (Huang et al., 2015) and the introduction of new products (Kaya, 2015) are the sources of competitive 
advantage). In the green marketing context, green innovation has become recognized as a key point to accrue firm's competitive advantage (Arseculeratne and Yazdanifard, 2014).

Previous study (Wong, 2012) has proven the effect of green innovation on the company's competitive advantage in the electrical and electronics industry in China. Another study (Chang, 2011) also found that green innovation served as a mediator for corporate environmental ethics and corporate competitive advantage. It is concluded that besides having an impact on environmental performance, green innovation also influenced the company's competitive advantage (Chiou et al., 2011)

Based on the discussion above, the research hypothesis is formed as follows: H2: green innovation positively affects green competitive advantage

Competitive Advantage and Company Performance. The resource-based view (RBV) theory reveals that firms which have unique resources capabilities would able to create competitive advantage which leads to superior performance achievement (Camisón and Villar-López, 2014). In addition, superior performance is an output of competitive advantage (Huang et al., 2015). The economic value as the base of competitive advantage is obtained from producing goods or services at the same cost as competitors with superior benefits (Newbert, 2008). This advantage will lead to positive perceived product quality and consumer loyalty. Companies can also gain advantages regarding cost structure, which enables companies to gain a competitive advantage regarding costs.

Previous studies have found the relationship between competitive advantage and company performance (Leonidou et al., 2013; Saeidi et al., 2015). Based on the description, the research hypothesis is formed as follows:

H3a: green competitive advantage affects green performance

H3b: green competitive advantage affects non-green performance

Green Performance and Non-Green Performance. The traditional perspectives consider companies' efforts to be green will increase costs and become a financial burden and reduce corporate profits (Rassier and Earnhart, 2010). On the other hand, there is an argument which states otherwise. Prior study (Chiou et al., 2011) revealed the importance of implementing a green business to enhance corporate image which turn to a superior performance. Further argument pointed out that firms will obtain a higher profit when conducting pollution prevention activities (Hart and Dowell, 2011).

The results of the study of the influence of environmental performance on company performance are still diverse (Lee et al., 2015). There is no empirical evidence that pollution reduction would contribute to the company's financial performance (Wong et al., 2012). However, another study (Delmas et al., 2013) found that environmental performance has a significant effect on firm's value. Also, companies which have concern on environment will perform better and result superior financial benefit (Gallego - Álvarez et al., 2014). Furthermore, pollution prevention effort which is conducted by firms will cause a cost saving (Muhammad et al., 2015).

Based on the description, the research hypothesis is formed as follows:

H4: green performance affects non-green performance.

Based on the arguments regard to the interrelationship of the concepts above, the proposed conceptual model and hypotheses are shown in figure 1. 


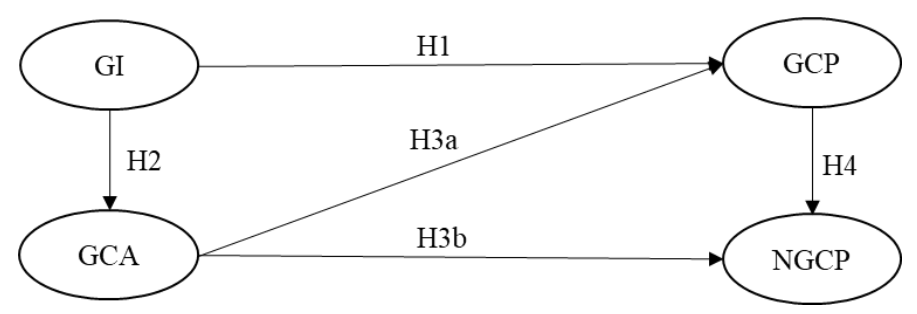

Figure 1. Conceptual Model

\section{METHODOLOGY}

Data Collection. We drew a sample of top management and owners of SMEs in five cities in Indonesia to examine the stated hypotheses. The contribution of SMEs to Indonesia's national income has increased in the last five years, from $57.84 \%$ to $60.34 \%$ (AHA/SON/NDY, 2018). The contribution to employment has also increased, from $96.99 \%$ to $97.22 \%$. However, SMEs in Indonesia have not developed optimally, partly due to weak innovations that have an impact on low competitiveness (Beselly and Mawardi, 2017; Ussisa, 2015). The survey method was employed to gather information from 200 respondents.

Measurement. The measurement of green innovation refers to previous study (Tseng et al., 2012), and use four indicators, green management innovation, green process innovation, green product innovation, and green technology innovation. Competitive advantage was measured by the superiority of company compared to competitors regarding pollution produced, waste produced, costs of handling waste and pollution, and environmental damage (Ge et al., 2016). The measurement of company performance is carried out using subjective measures (perceptions of respondents), which is claimed "the use of these perceived measures is also well established in the environmental management literature" (Chan et al., 2012, .p 625). The measurement of non-green company performance refers to previous studies (Bagur-Femenias et al., 2016; Chan et al., 2012), including sales growth, profit growth, customer satisfaction, and corporate image. The operationalization of the company's green performance using five indicators, namely: the pollution produced, the waste produced, the cost of handling waste and pollution, and environmental damage (Ge et al., 2016).

Structural Equation Modeling (SEM) analysis technique was performed to analyze the data. Factor analysis was employed to test the validity of the items.

\section{RESULTSAND DISCUSSION}

The Results of Statistical Test. Sample Profile. The sex of the respondents was dominated by men, with a proportion of $63.3 \%$. In terms of age, most of the respondents have a distribution between the ages of 18 and 50 years. As many as $38.2 \%$ of respondents have a higher education background (above high school).86.9\% of respondents are business owners. Most of the business respondents are engaged in manufacturing and culinary, which 
is as much as $59.8 \%$. Most of the respondents' businesses were established in less than 7 years $(63.4 \%)$. As many as $53.8 \%$ of respondents only have 1 to 10 employees; The other $27.6 \%$ do not even have employees. The majority of respondents stated that they have maximum assets of only Rp. 50 million. The result was directly proportional to the turnover achievement, where as many as $83.9 \%$ of respondents only have a maximum turnover of $\mathrm{Rp}$ 300 million.

Measurement Instrument Validation. Before measuring the research model, validity and reliability test was conducted to examine the robustness of the instrument. The maximum likelihood and the varimax rotated method were employed to extract the factor. Convergent and discriminant validity were used to test the construct validity. For reliability test, internal reliability and composite reliability test were employed. The results are shown in table 1.

Table 1. Results of Validity and Reliability Test

\begin{tabular}{|lcccc|}
\hline & Factor Loading & Cronbach $\alpha$ & AVE & CR \\
\hline Green Innovation & & .946 & .864 & .962 \\
GI 1 & .951 & & & \\
GI 2 & .943 & & & \\
GI 3 & .928 & & & \\
GI 4 & .897 & .935 & .793 & .950 \\
Green Competitive & & & & \\
Advantage & .865 & & & \\
GCA 1 & .885 & & & \\
GCA 2 & .910 & & & \\
GCA 3 & .908 & & & \\
GCA 4 & .885 & & & \\
GCA 5 & & & & \\
Non-Green & .935 & & \\
Performance & .912 & & & \\
NGCP 1 & .965 & & & \\
NGCP 2 & .965 & & & \\
NGCP 3 & .835 & & & \\
NGCP 4 & & & \\
Green Performance & .938 & & & \\
GCP 1 & .891 & & & \\
GCP 2 & .909 & & & \\
GCP 3 & .847 & & & \\
GCP 4 & & & \\
GCP 5 & .813 & & & \\
\hline
\end{tabular}

Bartlett's Test of Sphericity sig $=.000$

Source: Data processed (2018)

Based on the results of factor analysis in table 1, all indicators have a loading factor value above .60, which means all items are valid to use. The result is supported by the average variance extracted (AVE) value for all indicators greater than .50. Thus, based on the results of the convergent validity and discriminant validity test, instrument items are valid. For the results of the reliability test, all instruments have a Cronbach $\alpha$ value greater 
than .70 and the composite reliability value (CR) which is also greater than .70. Therefore, the research instrument has the required reliability.

In addition, we measured the goodness of fit of the measurement model. As seen at table 2, The fit indexes of CFA for the proposed model were adequate ( $\mathrm{p}$ value $=.544$, GFI $=.97, \mathrm{AGFI}=.95, \mathrm{RMSEA}=.00, \mathrm{CMIN} / \mathrm{DF}=.94)$, suggesting that the measurement model provided a good fit for the data.

Table 2. Results of Measurement Model's Goodness of Fit

\begin{tabular}{|lll|l|}
\hline Parameters & Criterion & Results & Conclusion \\
\hline Chi-Square Significance Probability & $\geq .05$ & .544 & Model is fit \\
RMSEA & $\leq .08$ & .000 & Model is fit \\
GFI & $\geq .90$ & .973 & Model is fit \\
AGFI & $\geq .90$ & .950 & Model is fit \\
CMIN/DF & $\leq 2.00$ & .949 & Model is fit \\
\hline
\end{tabular}

Source: Data processed (2018)

Hypotheses Testing. A goodness of fit test for the structural model was employed to test the robustness of the structural model. The results are shown in table 3 . The fit indexes of CFA for the structural model were adequate $(\mathrm{p}$-value $=.052$, GFI $=.97$, AGFI $=.898$, RMSEA $=.034$, CMIN/DF $=1.230$ ). Based on the goodness of fit test results, all of the parameters except for AGFI meet the criteria. The results demonstrate a satisfactory fit for the structural model.

Table 3. Results of Structural Model's Goodness of Fit

\begin{tabular}{|llll|}
\hline Parameters & Criterion & Results & Conclusion \\
\hline Chi-Square Significance Probability & $\geq .05$ & .052 & Model is fit \\
RMSEA & $\leq .08$ & .034 & Model is fit \\
GFI & $\geq .90$ & .935 & Model is fit \\
AGFI & $\geq .90$ & 0.898 & Model is not fit \\
CMIN/DF & $\leq 2.00$ & 1.230 & Model is fit \\
\hline
\end{tabular}

Source: Data processed (2018)

The final model with standardized path coefficients is shown in figure 2. The path coefficients were considered to support hypotheses if the value of C.R exceeds \pm 1.96 at .05 significance level. Table 4 demonstrates the results of hypotheses testing.

The association between green innovation and competitive advantage was found significant $(\beta=.17 ; p=.00)$ as well as the path between green competitive advantage and non-green performance $(\beta=.76 ; \mathrm{p}=.00)$. Thus, $\mathrm{H} 2$ and $\mathrm{H} 3 \mathrm{~b}$ accepted. On contrary, insignificant results found in the association between green innovation and green performance $(\beta=-.08 ; p=2.29)$, green competitive advantage and green performance $(\beta=$ $.02 ; \mathrm{p}=.885)$, as well as green performance and non-green performance $(\beta=-.02 ; \mathrm{p}=.731)$. $\mathrm{So}, \mathrm{H} 1, \mathrm{H} 3 \mathrm{a}$, and $\mathrm{H} 4$ rejected. 


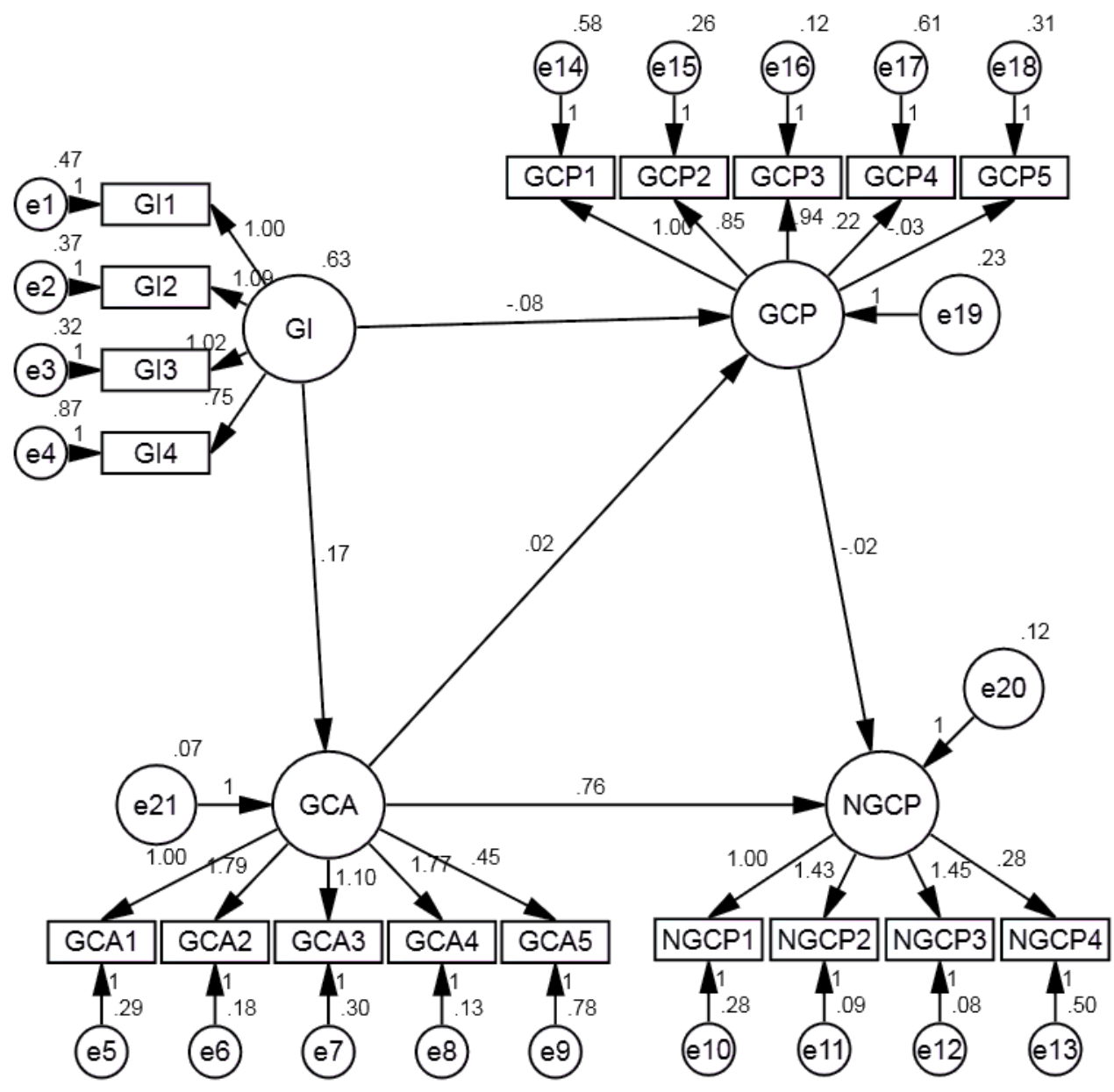

Figure 2. Full Model Testing

The results of SEM analysis in Figure 2. is summarized as the hypothesis testing results as seen in table 4 below:

Table 4. Results of Hypotheses Testing

\begin{tabular}{|llccl|}
\hline & & C.R & P & Results \\
\hline $\mathrm{H}_{1}$ & $\begin{array}{l}\text { Green innovation positively affects } \\
\text { green performance }\end{array}$ & -1.203 & .229 & Rejected \\
$\mathrm{H}_{2}$ & $\begin{array}{l}\text { Green innovation positively affects } \\
\text { green competitive advantage }\end{array}$ & 4.579 & $* * *$ & Accepted \\
$\mathrm{H}_{3 \mathrm{a}} \quad \begin{array}{l}\text { Green competitive advantage } \\
\text { affects green performance }\end{array}$ & .144 & .885 & Rejected \\
$\mathrm{H}_{\mathrm{b}}$ & $\begin{array}{l}\text { Green competitive advantage } \\
\text { affects non-green performance }\end{array}$ & 4.808 & $* * *$ & Accepted \\
$\mathrm{H}_{4}$ & $\begin{array}{l}\text { Green performance affects non- } \\
\text { green performance. }\end{array}$ & -.344 & .731 & Rejected \\
\hline
\end{tabular}

Source: Data processed (2018) 
Discussion. The evidence of the effect of green innovations on the advantages of green competitiveness is in line with previous studies (Ar, 2012; Chiou et al., 2011). The evidence of the effect of green competitive advantage on the non-green performance also following previous research (Leonidou et al., 2013; López-Gamero et al., 2009).

However, the investigation's result of green innovation on the green performance was not in line with the previous studies (Chiou et al., 2011; Huang and Li, 2017; Weng et al., 2015). The evidence of the effect of green innovations on non-green performance is also not following previous studies (Ar, 2012; Huang and Li, 2017; Weng et al., 2015). Furthermore, the results of examining the effect of green competitive advantage on green performance are not in line with prior studies.

We think the absence of the influence of innovation on green performance is caused by the time lag between the implementation of the innovation and the outcome. In this study, the green innovations were measured by asking innovations that had been carried out in the last two years. Likewise, the company performance was measured through items that ask for improved performance in the last two years. Thus, it is assumed that the innovation carried out directly has an impact on the company's performance. In fact, it may take a long time for the implementation of innovation to have an impact on the company's performance.

The argument for the absence of the influence of competitive advantage on company performance is explained in the conceptual model "the resource-based view and stakeholder bargaining power" (Coff, 1999). The model explained that human resources as the owners of intellectual assets that produce competitive advantage require compensation that makes them not to leave the organization. Ownership of intellectual assets by human resources makes them have bargaining power regarding obtaining compensation. Thus, the company performance, especially financial performance, will be affected. The financial performance of the company, for example, profits, can be considered a residue from various expenses, including expenses for HR compensation. Therefore, the stronger the bargaining power of HR will have an impact on the higher compensation they receive, and the smaller the proportion of the financial performance.

For the insignificant result of the impact of green performance on non-green performance, we suggest that the gains on financial performance should not be confined to pollution reduction. Efforts also should be spent on promotion activities since green promotion is an effective tool to influence consumer purchase intention and creating firm's positive image which leads a positive impact on firms' performance (Hasan and Ali, 2015).

The results and discussion imply the significant role of green innovation for SMEs. Therefore, SMEs should actively create a green innovation. Through green innovation, SMEs will have the capability to create a competitive advantage, which leads to the improvement of the SMEs 'performance. However, due to the limitation of resources, SMEs face challenging effort to implement green innovation. Knowledge and skill of the human resources and financial ability are things among other are factors that potentially discourage SMEs to be green.

Therefore, government intervention through policy to facilitate financial resources for green innovation held by SMEs is needed. In addition, optimizing government's role to develop networking will also a beneficial. For example, government can facilitate the utilization of the university's research to help SMEs to generate the ideas of green innovation. Furthermore, collaboration with other countries, such as establishing green 
business center with Korea recently, will give boost SMEs' awareness and concern toward environment as well as improving their competence to manage a green business.

\section{CONCLUSION}

This study aims to examine the effect of green innovation and competitive advantages on green performance and non-green performance of the company. Research respondents are owners and high-level managers of SMEs in Indonesia. The respondent's business sector includes the construction, manufacturing and processing sectors, plantations, trade, food and beverages, and services. Data analysis is done using the structural equation model technique.

The results of data analysis prove the existence of the influence of green innovations on the competitive advantage and the competitive advantage on the non-green performance of the company. However, this study failed to prove the influence of green innovation on green performance, competitive advantage on green performance, and green performance on non-green performance.

Regard to the findings and analysis; the study promotes the importance of green innovation to create sustainable competitive advantage and to improve company performance. This study also provides a valuable contribution to enhancing green innovation and company performance literature in the context of SMEs in developing countries, which is under-researched.

Limitation ad Suggestion for Future Research. This study does not serve the type of industry as a control variable because of the minimal amount of data obtained. For further research, we suggest the use of industrial types as a control variable with the consequence of increasing the number of samples. Besides, referring to the results of the descriptive analysis of variables about the low-level of green innovation generated by SMEs, then further research should investigate the factors that become obstacles for SMEs to conduct green innovation. In addition, future research should investigate the diffusion of innovation in the market since green innovation will not work properly unless green consumers are aware of and adopt the innovation.

\section{REFERENCES}

AHA/SON/NDY. (2018). Kontribusi UMKM Naik. Retrieved November 4, 2018, from http://www.kemenperin.go.id/artikel/14200/Kontribusi-UMKM-Naik.

Albertini, E. (2013). Does environmental management improve financial performance? A meta-analytical review. Organization \& Environment, 26(4), 431-457.

Andersen, M. M. (2012). Into the Green Economy - Evolutionary Perspectives on Green Economic Change. In Schumpeter Conference.

Andersen, M. M. (2015). Frugal Innovation and Green Business Models. In ISPIM Innovation Symposium (p. 1). Brisbane, Australia.

Ar, I. M. (2012). The impact of green product innovation on firm performance and competitive capability: the moderating role of managerial environmental concern. Procedia - Social and Behavioral Sciences, 62, 854-864. https://doi.org/10.1016/j.sbspro.2012.09.144.

Arseculeratne, D., and Yazdanifard, R. (2014). How Green Marketing Can Create a 
Sustainable Competitive Advantage for a Business. International Business Research, 7, 130-137.

Bagur-Femenias, L., Celma, D., and Patau, J. (2016). The adoption of environmental practices in small hotels. voluntary or mandatory? An empirical approach. Sustainability, 8(7), 695.

Berrone, P., Fosfuri, A., Gelabert, L., and Gomez - Mejia, L. R. (2013). Necessity as the mother of 'green'inventions: Institutional pressures and environmental innovations. Strategic Management Journal, 34(8), 891-909.

Beselly, X. D., and Mawardi, M. K. (2017). Kebijakan Pengembangan Daya Saing Global USAha Kecil Menengah (UKM) Di Kota Batu Menggunakan Sme Development Index. Jurnal Administrasi Bisnis, 47(1), 25-31.

Camisón, C., and Villar-López, A. (2014). Organizational innovation as an enabler of technological innovation capabilities and firm performance. Journal of Business Research, 67(1), 2891-2902.

Chan, H. K., Yee, R. W., Dai, J., and Lim, M. K. (2016). The moderating effect of environmental dynamism on green product innovation and performance. International Journal of Production Economics, 62, 854-864. https://doi.org/10.1016/j.sbspro.2012.09.144.

Chan, R. Y. K., He, H., Chan, H. K., and Wang, W. Y. C. (2012). Environmental orientation and corporate performance: The mediation mechanism of green supply chain management and moderating effect of competitive intensity. Industrial Marketing Management, 41, 621-630.

Chang, C., and Chang H., C. (2011). The Influence of Corporate Environmental Ethics on Competitive Advantage: The Mediation Role of Green Innovation. Journal of Business Ethics, 104, 361-370. https://doi.org/http://dx.doi.org/10.1007/s10551-0110914-X.

Chen, Y.-S., Lin, C.-Y., and Weng, C.-S. (2015). The Influence of Environmental Friendliness on Green Trust: The Mediation Effects of Green Satisfaction and Green Perceived Quality. Sustainability, 7, 10135-10152. https://doi.org/http://dx.doi.org/10.3390/su70810135.

Cheng, C. C. J., Yang, C., and Sheu, C. (2014). The link between eco-innovation and business performance: a Taiwanese industry context. Journal of Cleaner Production, 64, 81-90.

Cheng, C., and Shiu, E. (2012). Validation of a proposed instrument for measuring ecoinnovation: An implementation perspective. Technovation, 32(6), 329-344.

Chiou, T.-Y., Chan, H. K., Lettice, F., and Chung, S. H. (2011). The influence of greening the suppliers and green innovation on environmental performance and competitive advantage in Taiwan. Transportation Research Part E: Logistics and Transportation Review, 47, 822-836. https://doi.org/http://dx.doi.org/10.1016/j.tre.2011.05.016.

Chou, C.-J., Chen, K.-S., and Wang, Y.-Y. (2012). Green practices in the restaurant industry from an innovation adoption perspective: Evidence from Taiwan. International Journal of Hospitality Management, 31(3), 703-711.

Coff, R. W. (1999). When competitive advantage doesn't lead to performance: The resource-based view and stakeholder bargaining power. Organization Science, 10(2), $119-133$.

Covino, D., Boccia, F., and Cesaretti, G. P. (2013). Globalization and rules for well-being 
sustainability. Rivista Di Studi Sulla Sostenibilità, 1, 93-107.

Del Río, P., Peñasco, C., and Romero-Jordán, D. (2016). What drives eco-innovators? A critical review of the empirical literature based on econometric methods. Journal of Cleaner Production, 112, 2158-2170.

Delmas, M. A., Etzion, D., and Nairn-Birch, N. (2013). Triangulating environmental performance: What do corporate social responsibility ratings really capture? Academy of Management Perspectives, 27(3), 255-267.

Doran, J., and Ryan, G. (2012). Regulation and firm perception, eco-innovation and firm performance. European Journal of Innovation Management, 15, 421-441. https://doi.org/10.1108/14601061211272367.

Dowell, G., and Hart, S. (2011). A Natural-Resource-Based View of the Firm: Fifteen Years After. Journal of Management, 37(5), 1464-1479.

Fauzi, H., Svensson, G., and Rahman, A. A. (2010). "Triple Bottom Line" as "Sustainable Corporate Performance”: A Proposition for the Future. Sustainability, 2, 1345-1360. https://doi.org/http://dx.doi.org/10.3390/su2051345.

Fraj, E., Martínez, E., \& Matute, J. (2011). Green marketing strategy and the firm 's performance: the moderating role of environmental culture. Journal of Strategic Marketing, 19, 339-355. https://doi.org/10.1080/0965254X.2011.581382.

Gallego - Álvarez, I., García - Sánchez, I. M., and da Silva Vieira, C. (2014). Climate change and financial performance in times of crisis. Business Strategy and the Environment, 23(6), 361-374.

Ge, B., Jiang, D., Gao, Y., and Tsai, S.-B. (2016). The Influence of Legitimacy on a Proactive Green Orientation and Green Performance: A Study Based on Transitional $\begin{array}{lllll}\text { Economy Scenarios in China. Sustainability, 8, } 1344 . & \end{array}$ https://doi.org/http://dx.doi.org/10.3390/su8121344.

Gholami, R., Sulaiman, A. B., Ramayah, T., and Molla, A. (2013). Senior managers' perception on green information systems (IS) adoption and environmental performance: Results from a field survey. Information \& Management, 50, 431-438. https://doi.org/10.1016/j.im.2013.01.004.

Guoyou, Q., Saixing, Z., Chiming, T., Haitao, Y., and Hailiang, Z. (2013). Stakeholders' influences on corporate green innovation strategy: a case study of manufacturing firms in China. Corporate Social Responsibility and Environmental Management, 20(1), 114.

Harrison, J. S., and Wicks, A. C. (2013). Stakeholder theory, value, and firm performance. Business Ethics Quarterly, 23(1), 97-124.

Hasan, Z., and Ali A., N. (2015). The Impact of Green Marketing Strategy on the Firm's Performance in Malaysia. Procedia - Social and Behavioral Sciences, 172, 463-470. https://doi.org/10.1016/j.sbspro.2015.01.382.

Henriksen, K. (2011). Green Business Model Innovation-A shortcut to green growth \& competitiveness. US EPA "s Green Servicing Workshop. FORA.

Henriksen, K., Bjerre, M., Øster, J., and Bisgaard, T. (2012). Green Business Model Innovation-Policy report. Nordic Council of Ministers.

Huang, J.-W., and Li, Y.-H. (2017). Green innovation and performance: The view of organizational capability and social reciprocity. Journal of Business Ethics, 145(2), 309-324.

Huang, K., Dyerson, R., Wu, L., and Harindranath, G. (2015). From temporary competitive 
advantage to sustainable competitive advantage. British Journal of Management, 26(4), 617-636.

Kaya, N. (2015). Corporate Entrepreneurship, Generic Competitive Strategies, and Firm Performance in Small and Medium-sized Enterprises. Procedia - Social and Behavioral Sciences, 207, 662-668. https://doi.org/http://dx.doi.org/10.1016/j.sbspro.2015.10.136.

Kesidou, E., and Demirel, P. (2012). On the drivers of eco-innovations: Empirical evidence from the UK. Research Policy, 41(5), 862-870.

Klewitz, J., and Hansen, E. G. (2014). Sustainability-oriented innovation of SMEs: a systematic review. Journal of Cleaner Production, 65, 57-75.

Laosirihongthong, T., Adebanjo, D., and Tan, K. C. (2013). Green supply chain management practices and performance. Industrial Management \& Data Systems, 113, 1088-1109. https://doi.org/10.1108/IMDS-04-2013-0164.

Lee, K.-H., Min, B., and Yook, K.-H. (2015). The impacts of carbon (CO2) emissions and environmental research and development $(\mathrm{R} \& \mathrm{D})$ investment on firm performance. International Journal of Production Economics, 167, 1-11.

Leonidou, L. C., Leonidou, C. N., Fotiadis, T. A., and Zeriti, A. (2013). Resources and capabilities as drivers of hotel environmental marketing strategy: Implications for competitive advantage and performance. Tourism Management, 35, 94-110.

López-Gamero, M. D., Molina-Azorín, J. F., and Claver-Cortes, E. (2009). The whole relationship between environmental variables and firm performance: Competitive advantage and firm resources as mediator variables. Journal of Environmental Management, 90(10), 3110-3121.

Muhammad, N., Scrimgeour, F., Reddy, K., and Abidin, S. (2015). The relationship between environmental performance and financial performance in periods of growth and contraction: evidence from Australian publicly listed companies. Journal of Cleaner Production, 102, 324-332. https://doi.org/http://dx.doi.org/10.1016/j.jclepro.2015.04.039.

Negny, S., Belaud, J., Robles, C., Reyes, R., and Ferrer, B. (2012). Toward an ecoinnovative method based on a better use of resources: application to chemical process preliminary design. Journal of Cleaner Production, 32, 101-113.

Newbert, S. L. (2008). Value, rareness, competitive advantage, and performance: a conceptual - level empirical investigation of the resource - based view of the firm. Strategic Management Journal, 29(7), 745-768.

Oxborrow, L., and Brindley, C. (2013). Adoption of "eco-advantage"by SMEs: emerging opportunities and constraints. European Journal of Innovation Management, 16. https://doi.org/10.1108/EJIM-09-2011-0079.

Peng, X., and Liu, Y. (2016). Behind eco-innovation: Managerial environmental awareness and external resource acquisition. Journal of Cleaner Production, 139, 347-360.

Pinget, A., Bocquet, R., and Mothe, C. (2015). Barriers to environmental innovation in SMEs: Empirical evidence from French firms. M@n@gement, 18(2), 132-155. https://doi.org/10.3917/mana.182.0132.

Powell, T. C. (2001). Competitive advantage: logical and philosophical considerations. Strategic Management Journal, 22(9), 875-888.

Rassier, D. G., and Earnhart, D. (2010). Does the porter hypothesis explain expected future financial performance? The effect of clean water regulation on chemical 
manufacturing firms. Environmental and Resource Economics, 45(3), 353-377.

Rosenbusch, N., Brinckmann, J., and Bausch, A. (2011). Is innovation always beneficial? A meta-analysis of the relationship between innovation and performance in SMEs. Journal of Business Venturing, 26(4), 441-457.

Saeidi, S. P., Sofian, S., Saeidi, P., Saeidi, S. P., and Saaeidi, S. A. (2015). How does corporate social responsibility contribute to firm financial performance? The mediating role of competitive advantage, reputation, and customer satisfaction. Journal of Business Research, 68(2), 341-350.

Sáez-Martínez, F. J., Díaz-García, C., and González-Moreno, Á. (2016). Factors promoting environmental responsibility in European SMEs: The effect on performance. Sustainability, 8(9), 898.

Schaltegger, S. (2011). Sustainability as a driver for corporate economic success: Consequences for the development of sustainability management control. Society and Economy, 33(1), 15-28.

Schiederig, T., Tietze, F., and Herstatt, C. (2012). Green innovation in technology and innovation management-an exploratory literature review. $R \& d$ Management, 42(2), 180-192.

Strand, R., and Freeman, R. E. (2015). Scandinavian cooperative advantage: The theory and practice of stakeholder engagement in Scandinavia. Journal of Business Ethics, $127(1), 65-85$.

Triguero, A., Moreno-Mondéjar, and M., L. D. (2013). Drivers of different types of ecoinnovation in European SMEs. Ecological Economics, 92, 25-33.

Trumpp, C., Endrikat, J., Zopf, C., and Guenther, E. (2015). Definition, conceptualization, and measurement of corporate environmental performance: A critical examination of a multidimensional construct. Journal of Business Ethics, 126(2), 185-204.

Tseng, M.-L., Huang, F., and Chiu, A. S. F. (2012). Performance drivers of green innovation under incomplete information. Procedia-Social and Behavioral Sciences, 40, 234250.

Ussisa, U. (2015). Problematika Apa Saja yang Dihadapi UMKM di Indonesia? Retrieved from https://www.kompasiana.com/ussisa/565e27124623bdb70eba545b/problematikaapa-saja-yang-dihadapi-umkm-di-indonesia?page=all.

Verde, C. (2015). Strategy and Green Business Model: The Case of Carlsberg Group. Calitatea, $16, \quad 75-79 . \quad$ Retrieved from https://search.proquest.com/docview/1726773661 ?accountid=35143.

Weng, H.-H. (Robin), Chen, J.-S., and Chen, P.-C. (2015). Effects of Green Innovation on Environmental and Corporate Performance: A Stakeholder Perspective. Sustainability, 7, 4997-5026. https://doi.org/10.3390/su7054997.

Weng, M.-H., and Lin, C.-Y. (2011). Determinants of green innovation adoption for small and medium-size enterprises (SMES). African Journal of Business Management, 5(22), 9154-9163.

Wong, C. W. Y., Lai, K., Shang, K.-C., Lu, C.-S., and Leung, T. K. P. (2012). Green operations and the moderating role of environmental management capability of suppliers on manufacturing firm performance. International Journal of Production Economics, 140(1), 283-294.

Wong, S. K. S. (2012). The influence of green product competitiveness on the success of 
green product innovation: Empirical evidence from the Chinese electrical and electronics industry. European Journal of Innovation Management, 15(4), 468-490.

Wong, W.-P., Tseng, M.-L., and Tan, K. H. (2014). A business process management capabilities perspective on organisation performance. Total Quality Management \& Business Excellence, 25(5-6), 602-617.

Zhang, H., Liang, X., and Wang, S. (2016). Customer value anticipation, product innovativeness, and customer lifetime value: The moderating role of advertising strategy. Journal of Business Research, 69(9), 3725-3730.

Zhang, J. A., and Walton, S. (2016). Eco - innovation and business performance: the moderating effects of environmental orientation and resource commitment in green oriented SMEs. $R \& D$ Management. 